Jurnal Analis Laboratorium Medik

Avalilable Online http://e-journal.sari-mutiara.ac.id/index.php/ALM

DOI: https://doi.org/10.51544/jalm.v6i1.1837

\title{
ANALISIS LOGAM BERAT PADA SAYURAN YANG DITANAMI DI PINGGIR JALAN BEKASI UTARA
}

\author{
Ing Mayfa Br Situmorang ${ }^{1}$ Dimas Frananta Simatupang ${ }^{2}$ \\ ${ }^{1}$ Program Studi Teknologi Laboratorium \\ Medis, STIKes Prima Indonesia \\ Email:ingmayfasitumorang@gmail.com \\ ${ }^{2}$ Program Studi Teknik Kimia,Politeknik \\ Teknologi Kimia Industri Medan \\ Email:difratas@ptki.ac.id
}

Received: Januari 2021; Accepted: April 2021; Published: Juni 2021

\begin{abstract}
ABSTRAK
Bekasi termasuk kawasan peri-urban yang memiliki potensi terkena dampak pencemaran tanah, air dan udara. Bahan pencemar lingkungan berupa logam berat, dapat terakumulasi pada produk pertanian. Sayuran yang terkontaminasi oleh logam berat dapat menyebabkan bio akumulasi unsur-unsur beracun dan menjadi penyebab penyakit di dalam tubuh manusia. Tujuan penelitian ini adalah mengetahui kandungan logam berat yang terdapat pada sayur-sayuran yang ditanam dipinggir jalan raya. Sampel penelitian adalah bayam hijau, bayam merah dan kangkung yang ditanam dipinggir jalan raya oleh petani yang ada di sekitar STIKes Prima Indonesia Kecamatan Babelan, Bekasi Utara. Kandungan logam berat yang menjadi focus peneliti yaitu timbal $(\mathrm{Pb})$, krom $(\mathrm{Cr})$, arsen $(\mathrm{As})$ dan Tembaga $(\mathrm{Cu})$ pada sayur bayam hijau, bayam merah dan kangkung dengan menggunakan metode destruksi basah dengan menggunakan instrument spektroskopi serapan atom (SSA). Hasil analisis kandungan logam berat pada sayuran kangkung terdapat kadar timbal $(\mathrm{Pb})$ dan krom $(\mathrm{Cr})$ yang tinggi sedangkan Arsen $(\mathrm{As})$ dan Tembaga $(\mathrm{Cu})$ tidak terdeteksi. Pada sayuran bayam hijau dan bayam merah memiliki kadar krom $(\mathrm{Cr})$ yang tinggi dan untuk timbal $(\mathrm{Pb})$, Arsen (As) dan Tembaga $(\mathrm{Cu})$ tidak terdeteksi. Adapun kesimpulan dalam penelitian ini adalah sayuran kangkung memiliki jumlah kandungan logam timbal yang sangat tinggi dan pada sayuran bayam merah, sayuran hijau dan kangkung memiliki jumlah kandungan logam krom yang tinggi.
\end{abstract}

Kata Kunci : Sayuran; Logam Berat;spektroskopi serapan atom (SSA).

\section{ABSTRACT}

Bekasi is a peri-urban area that has the potential to be impacted by soil, water and air pollution. Environmental pollutants such as heavy metals, could be accumulated in agricultural products. Vegetables contaminated by heavy metals can cause bioaccumulation of toxic elements and cause disease in the human body. The purpose of this study was to determine the content of heavy metals found in vegetables planted on the side of the highway. The research samples were green spinach, red spinach and water spinach planted on the side of the highway by farmers around STIKes Prima Indonesia, Babelan District, NorthBekasi. The heavy metal content that the researchers focused on were lead $(\mathrm{Pb})$, chromium (Cr), arsenic (As) and copper $(\mathrm{Cu})$ in green spinach, red spinach and kale using the wet digestion method through atomic absorption spectroscopy (AAS) instruments. The results of the analysis of heavy metal content in kale vegetables contained high levels of lead $(\mathrm{Pb})$ and chromium $(\mathrm{Cr})$ while arsenic $(\mathrm{As})$ and copper $(\mathrm{Cu})$ were not detected. Green spinach and red spinach had high levels of chromium $(\mathrm{Cr})$ and undetectable lead $(\mathrm{Pb})$, arsenic (As) and copper $(\mathrm{Cu})$. The conclusion in this study was that kale vegetables had a very high amount of lead metal content and the three vegetables had a high amount of chromium metal content.

Keywords : Vegetables; heavy metals; atomic absorption spectroscopy (AAS) 


\section{PENDAHULUAN}

Kawasan peri-urban adalah kawasan yang letaknya dihimpit antara kota dan desa, selain itu kawasan tersebut memiliki potensi terkena dampak pencemaran tanah, air dan udara. Bahan pencemar lingkungan berupa logam berat, dapat terakumulasi pada produk pertanian. Sayur-sayuran merupakan bagian yang sangat penting dalam piramida makanan, keamanannya sangat penting dari sudut pandang kesehatan masyarakat. Sayuran yang terkontaminasi oleh logam berat dapat menyebabkan bioakumulasi unsur-unsur beracun dan menjadi penyebab penyakit di dalam tubuh manusia. Penelitian Delbari dan Kulkami (2013) menunjukkan adanya akumulasi logam berat cadmium $(\mathrm{Cd})$, timbal $(\mathrm{Pb})$, zink $(\mathrm{Zn})$, tembaga $(\mathrm{Cu})$, besi $(\mathrm{Fe})$, mangan $(\mathrm{Mn})$, nikel $(\mathrm{Ni})$ dan krom (Cr) pada tanaman disekitar jalan raya di beberapa kota di India.

Sayur-sayuran yang ditanam dipinggir jalan sangat berpotensi memiliki resiko terpapar oleh logam berat, yang dapat mengakibatkan sebagian sayuran mengandung logam berat yang membahayakan kesehatan manusia. Menurut Sharma, et al., (2009), akumulasi logam berat terjadi pada sayuran yang telah dipanen dan terpapar emisi kendaraan bermotor. Logam berat merupakan unsure logam yang memiliki berat molekul yang tinggi. Logam berat dapat mengakibatkan keracunan bagi tumbuhan dan hewan, termasuk manusia. Kandungan gizi yang terdapat pada sayuran dapat mengubah kualitas dan kuantitasnya karena beberapa factor, yakni penanganan pasca panen dan cara pengolahan. Menurut Joshi \&Swani (2009) menyatakan bahwa penurunan kualitas lingkungan berpengaruh pada komposisi kandungan senyawa biokimia dalam jaringan tanaman.

Berdasarkan hasil penelitian yang dilakukan di beberapa kawasan peri-urban yang ada di Indonesia, seperti penelitian Adila, et.al., (2014) melaporkan kandungan unsur timbal pada sayuran kangkung yang dianalisis dengan spekrtoskopi serapan atom (SSA) yang terdapat di tiga lokasi pasar tradisional Kecamatan Cilandak telah melebihi kadar ambang batas maksimum untuk sayuran menurut SNI 7387 tahun 2009. Menurut Rinawati \& Sofiatun (2018), kadar logam berat pada sayuran segar di kota Tangerang yaitu jenis kangkung, bayam dan sawi adalah Cd (Kadmium). Residu logam berat pada sampel bayam $(0,23 \mathrm{ppm})$, kangkung $(0,3 \mathrm{ppm})$ berada diatas Batas Maksimum Residu yang dipersyaratkan 0,2 ppm (BSN), sedangkan sawi masih dibawah batas Baku Mutu Residu yaitu 0,19 ppm .

Berdasarkan hal tersebut, peneliti tertarik untuk melakukan penelitian di daerah peri-urban yang ada di Bekasi, mengingat dampak yang diakibatkan pada kawasan tersebut. Tujuan penelitian ini adalah mengetahui kandungan logam berat yang terdapat pada sayur-sayuran yang ditanam dipinggir jalan raya.

Daerah yang akan menjadi tempat untuk mencapai tujuan tersebut adalah di STIKes Prima Indonesia Kecamatan Babelan, Bekasi Utara. Sayur-sayuran yang akan menjadi sampel penelitian adalah sayur bayam hijau, bayam merah dan kangkung dari petani yang menanam dipinggir jalan raya kecamatan Babelan. Kandungan logam berat yang menjadi focus peneliti yaitu timbal $(\mathrm{Pb})$, krom $(\mathrm{Cr})$, arsen (As) dan Tembaga $(\mathrm{Cu})$ pada sayur bayam hijau, bayam merah dan kangkung dengan menggunakan metode destruksi basah dengan instrument sprektroskopi serapan atom (SSA) dan mengetahui kelayakan sayur sawi dan kangkung untuk dikonsumsi oleh masyarakat sekitar. SSA merupakan instrumen yang digunakan untuk analisis kuantitatif dengan memberikan kadar total unsure logam yang terdapat dalam suatu sampel dan tidak tergantung pada bentuk molekul dari logam yang dianalisis di dalam sampel. SSA memiliki kepekaan yang tinggi batas deteksi yakni kurang dari 11 ppm, sehingga sangat tepat untuk menganalisis zat pada konsentrasi rendah dan tidak selalu memerlukan sumber energi yang besar(Yusuf et al., 2016). 


\section{METODE PENELITIAN}

Daerah yang akan menjadi tempat untuk mencapai tujuan tersebut adalah di STIKes Prima Indonesia Kecamatan Babelan, Bekasi Utara. Sayur-sayuran yang akan menjadi sampel penelitian adalah sayur bayam hijau, bayam merah dan kangkung dari petani yang menanam dipinggir jalan raya kecamatan Babelan. Kandungan logam berat yang menjadi focus peneliti yaitu timbal $(\mathrm{Pb})$, krom $(\mathrm{Cr})$, arsen (As) dan Tembaga $(\mathrm{Cu})$ pada sayur bayam hijau, bayam merah dan kangkung dengan menggunakan metode destruksi basah dengan instrument sprektroskopi serapan atom (SSA).

\section{HASIL DAN PEMBAHASAN}

Berdasarkan hasil analisis pada sayuran kangkung dengan menggunakan AAS sebagai berikut :

Tabel 5.1 Hasil Analisis Logam Berat pada sayuran kangkung menggunakan AAS
Tabel 5.2 Hasil Analisis Logam Berat pada sayuran bayam hijau menggunakan AAS

\begin{tabular}{llll}
\hline No & $\begin{array}{l}\text { Parameter } \\
\text { Logam }\end{array}$ & $\begin{array}{l}\text { Hasil } \\
\text { Pengukuran }\end{array}$ & $\begin{array}{l}\text { Konsentrasi } \\
(\mathrm{mg} / \mathrm{Kg})\end{array}$ \\
\hline 1 & Timbal $(\mathrm{Pb})$ & $<0,035 \mathrm{mg} / \mathrm{L}$ & Tidak terdeteksi \\
2 & Krom $(\mathrm{Cr})$ & $0,9971 \mathrm{mg} / \mathrm{L}$ & $33,24 \mathrm{mg} / \mathrm{Kg}$ \\
3 & Arsen $(\mathrm{As})$ & $<0,001 \mathrm{mg} / \mathrm{L}$ & Tidak terdeteksi \\
4 & Tembaga & $<0,062 \mathrm{mg} / \mathrm{L}$ & Tidak terdeteksi \\
& $(\mathrm{Cu})$ & & \\
\hline
\end{tabular}

Berdasarkan tabel 5.2 diperoleh hasil bahwa pada sayuran bayam hijau terdapat kadar krom $(\mathrm{Cr})$ yang tinggi.

Berdasarkan hasil analisis pada sayuran bayam merah dengan menggunakan AAS sebagai berikut :

Tabel 5.3 Hasil Analisis Logam Berat pada sayuran bayam merah menggunakan AAS

\begin{tabular}{|c|c|c|c|c|c|c|c|}
\hline No & $\begin{array}{l}\text { Parameter } \\
\text { Logam }\end{array}$ & $\begin{array}{l}\text { Hasil } \\
\text { Pengukuran }\end{array}$ & $\begin{array}{l}\text { Konsentrasi } \\
(\mathrm{mg} / \mathrm{Kg})\end{array}$ & No & $\begin{array}{l}\text { Parameter } \\
\text { Logam }\end{array}$ & $\begin{array}{l}\text { Hasil } \\
\text { Pengukuran }\end{array}$ & $\begin{array}{l}\text { Konsentrasi } \\
(\mathrm{mg} / \mathrm{Kg})\end{array}$ \\
\hline & & & & 1 & Timbal & $<0,035 \mathrm{mg} / \mathrm{L}$ & Tidak terdeteksi \\
\hline 1 & Timbal $(\mathrm{Pb})$ & $2,4595 \mathrm{mg} / \mathrm{L}$ & $81,983 \mathrm{mg} / \mathrm{Kg}$ & & $(\mathrm{Pb})$ & & \\
\hline 2 & $\operatorname{Krom}(\mathrm{Cr})$ & $1,3294 \mathrm{mg} / \mathrm{L}$ & $44,313 \mathrm{mg} / \mathrm{Kg}$ & 2 & Krom $(\mathrm{Cr})$ & $0,6652 \mathrm{mg} / \mathrm{L}$ & $22,17 \mathrm{mg} / \mathrm{Kg}$ \\
\hline 3 & Arsen (As) & $<0,001 \mathrm{mg} / \mathrm{L}$ & Tidak terdeteksi & 3 & Arsen (As) & $<0,001 \mathrm{mg} / \mathrm{L}$ & Tidak terdeteksi \\
\hline 4 & $\begin{array}{l}\text { Tembaga } \\
(\mathrm{Cu})\end{array}$ & $<0,062 \mathrm{mg} / \mathrm{L}$ & Tidak terdeteksi & 4 & $\begin{array}{l}\text { Tembaga } \\
(\mathrm{Cu})\end{array}$ & $<0,062 \mathrm{mg} / \mathrm{L}$ & Tidak terdeteksi \\
\hline
\end{tabular}

Berdasarkan tabel 5.1 diperoleh hasil bahwa pada sayuran kangkung terdapat kadar timbal $(\mathrm{Pb})$ dan krom $(\mathrm{Cr})$ yang tinggi.

Berdasarkan hasil analisis pada sayuran bayam hijau dengan menggunakan AAS sebagai berikut :
Pencemaran kromium berasal dari buangan industri-industri pelapisan krom, pabrik tekstil, pabrik cat, penyamakan kulit, pabrik tinta dan pengilangan minyak. Hal tersebut berasal dari natrium kromat dan natrium dikromat yang merupakan spesies krom (VI) bersifat toksik sebagai bahan pokok untuk memproduksi bahan kimia krom, seperti bahan pewarna krom, garamgaram krom yang dipergunakan penyamakan kulit, pengawetan kayu, bahan anti korosif pada 
Ing Mayfa Br Situmorang et.all/ Analisis Logam Berat Pada Sayuran Yang Ditanami Di Pinggir Jalan Bekasi Utara

peralatan otomotif, ketel dan pengeboran minyak (Adhani \& Husnain, 2017).

Lokasi pengambilan sampel dekat dengan bengkel mobil. Sehingga kemungkinan sayuran terkontaminasi oleh logam krom disebabkan oleh bengkel perbaikan body mobil sedangkan adanya kontaminasi timbal yang tinggi pada sayuran kangkung disebabkan oleh asap kendaraan bermotor. Berdasarkan Surat Keputusan DitJend POM No 03725/B/SKVII/89 menyatakan bahwa batas maksimum timbal yaitu $2 \mathrm{mg} / \mathrm{Kg}$ sehingga sayuran tersebut tidak aman untuk dikonsumsi.

Paparan jumlah yang lebih tinggi dari senyawa kromium pada manusia dapat menyebabkan penghambatan eritrosit glutathione reduktase, yang pada gilirannya menurunkan kapasitas untuk mengurangi methemoglobin dengan hemoglobin. Sedangkan Hasil yang diperoleh dari berbagai in vitro dan in vivo percobaan telah menunjukkan bahwa senyawa kromat dapat menyebabkan kerusakan DNA dalam berbagai cara dan dapat menyebabkan pembentukan adduct DNA, penyimpangan kromosom, pertukaran kromatit, perubahan dalam replikasi dan transkripsi dari DNA (Adhani\&Husnain, 2017).

Efek keracunan timbal kronis terjadi sebagai akibat paparan timbal yang terakumulasi pada kurun waktu bulanan hingga tahunan. Efek keracunan timbal kronis biasanya menimbulkan gejala yang tidak spesifik pada hampir semua system tubuh. Efek negative keracunan timbal kronis pada manusia terdiri atas penurunan libido dan kesuburan (jantan dan betina), keguguran dan kelahiran premature masalah kecerdasan, hipertensi, penyakit kardiovaskuler, lebih agresif, serta gangguan fungsi ginjal (Adhani\&Husnain, 2017).

\section{SIMPULAN}

Adapun kesimpulan dalam penelitian ini adalah sayuran kangkung memiliki jumlah kandungan logam timbal yang sangat tinggi dan pada sayuran bayam merah, sayuran hijau dan kangkung memiliki jumlah kandungan logam krom yang tinggi.

\section{DAFTARPUSTAKA}

1. Delbari AS, Kulkarni DK. Determination of Heavy Metal Pollution in Vegetables Grown Along The Roadside in Tehran Iran. Annals of Biological Research. 4 (2): 224-233.2013

2. Sharma ARK, Agrawal AM, Marshall BFM. Heavy Metals in Vegetables Collected from Production and Market Sites of A Tropical Urban Area of India. Food and Chemical Toxicology 47:583591. 2009

3. Joshi PC, SwamiA.,.Air pollution induced changes in the photosynthetic pigments of selected plant species. J. Environ. Biol. 30(2), 295-298. 2009.

4. Adila, Mirjani., Thamzil Laz., \& Etyn Yunita. Kadar Unsur Timbal pada tanaman Kangkung Di Tiga Pasar Tradisional Kecamatan Cilandak, Jakarta Selatan. Al-Kauniyah jurnal Biologi Vol 7 No 2. Jakarta. 2014.

5. SNI. SNI Nomor 7387-2009 Tentang Batas Maksimum Cemaran Logam Berat dalam Bahan Pangan. Badan Standarisasi Nasional. ICS.67.220.20. Jakarta. 2009.

6. SK Menteri Negara LH yang bernomor Kep 03/MENKLH/11/1991 Tentang Baku Mutu Limbah Cair Bagi Kesehatan Yang Sudah Beroperasi. Jakarta. 1991

7. Surat Keputusan DirJend POM No 03725/B/SKVII/89 Tentang Batas Maksimum Cemaran Logam Dalam Makanan.Jakarta. 1989.

8. Yusuf, M, Kiki Nurtjhaja, Rosliana Lubis. Analisis Kandungan Logam $\mathrm{Pb}, \mathrm{Cu}, \mathrm{Cd}$, dan Zn pada Sayuran Sawi, Kangkung Dan Bayam di Areal Pertanian dan Industri Desa Paya Rumput Titipan Medan. Jurnal Biologi Lingkungan, Industri, Kesehatan. Biolink Vol. 3 pISSN 2356-456x. 2016.

9. Adhani, Rosihan \& Husaini. 2017. Logam Berat Sekitar Manusia. Lambung Mangkurat University Press. Banjarmasin

10. Standard Nasional Indonesia (SNI 7387 :2009) tentang Batas Maksimum Logam Berat Dalam Pangan. 